\title{
Mineral deposition in tissues of cattle fed with different phosphates and relationships phosphorus: fluorine
}

\author{
Deposição de minerais em tecidos de bovinos alimentados com diferentes fosfatos e \\ relações fósforo:flúor
}

TEIXEIRA, Alexandre de Oliveira ${ }^{1 *}$; LEONEL, Fernando de Paula ${ }^{1}$; KNOOP, Rainer ${ }^{2}$; FERREIRA, Vanusa Patrícia de Araújo ${ }^{1}$; RIBEIRO, Everton Teixeira ${ }^{3}$; MOREIRA, Leonardo Marmo ${ }^{1,3}$; PEREIRA, José Carlos ${ }^{3}$

\author{
${ }^{1}$ Universidade Federal de São João del-Rei, Departamento de Zootecnia, São João del-Rei, Minas \\ Gerais, Brasil. \\ ${ }^{2}$ Consultor Independente, São Paulo, São Paulo, Brasil. \\ ${ }^{3}$ Universidade Federal de Viçosa, Departamento de Zootecnia, Viçosa, Minas Gerais, Brasil. \\ *Endereço para correspondência: alexandre_teixeira@ufsj.edu.br
}

\section{SUMMARY}

Forty-nine male calves were allotted in a randomized design, initially seven replicates per treatment at the end of the experiment were slaughtered four animals per treatment. Treatments CONT: control diet; FBC120: Dicalcium Phosphate 120:1 ratio P: F; MBC60: Monodicalcium phosphate 60:1 ratio $\mathrm{P}: \mathrm{F}$; FBC30: Dicalcium Phosphate 30:1 ratio P:F; SFT30: Super triple phosphate 30:1 ratio P:F; FBC10: Dicalcium Phosphate 10:1 ratio P:F; CAR10: concentrated ratio of 10:1 rock Q:F. Phosphates less elaborate showed higher amounts of heavy metals. In bones, iron, aluminum and lead were higher in FBC10 diet, the copper content was higher in animals fed the diet MBC60. Magnesium in liver was higher in animals fed diet FBC30, aluminum was higher for treatments SFT30 and FBC10, FBC120 and the cadmium and lead levels were higher in animals that received STF30. Treatments did not affect phosphorus and fluorine in muscle and heart, being that chromium was higher in the muscle of animals fed diets CAR10 and STF30 while cadmium in heart was greater in diet CAR10. Kidney phosphorus was higher in the animals fed the diet CAR10 and lower dietary $\mathrm{FBC10}$, while aluminum was higher in the animals fed with the diet $\mathrm{FBC} 10$ and lower dietary FBC120 and levels of chromium and lead were higher in animals CAR10 diet and lowest in diet MBC60. Alternative sources of phosphorus and low ratios P:F increased the deposition of minerals in bones and liver, and this mineral deposition was lower in the muscles.

Keywords: cadmium, heavy metals, liver, muscle, nutrition

\section{RESUMO}

Quarenta e nove novilhos machos foram distribuídos em delineamento casualizado, inicialmente com sete repetições por tratamento, sendo que, ao final do experimento, foram abatidos quatro animais por tratamento. Os tratamentos foram CONT: Dieta controle; FBC120: Fosfato Bicálcico 120:1 de relação P:F; MBC60: Fosfato monobicálcico 60:1 de relação P:F; FBC 30:1: Fosfato Bicálcico 30:1 de relação P:F; SFT30: Super Fosfato Triplo 30:1 de relação P:F; FBC10: Fosfato Bicálcico 10:1 de relação P:F; CAR10: Concentrado de Rocha 10:1 de relação P:F. Os fosfatos menos elaborados apresentaram maiores concentrações de metais. Nos ossos, os teores de ferro, alumínio e chumbo foram maiores para a dieta FBC10, enquanto o cobre foi maior na dieta MBC60. Magnésio foi mais presente no fígado de animais que consumiram a dieta FBC30, enquanto alumínio foi maior para SFT30, FBC10 e FBC120; cádmio e chumbo foram maiores para a dieta STF30. Os tratamentos não influenciaram fósforo e flúor em coração e músculos. $\mathrm{O}$ cromo foi mais presente no 
músculo de CAR10 e STF30 e o cádmio foi mais encontrado nos corações de CAR10. Nos rins, fósforo foi mais presente na dieta CAR10 e menor na dieta $\mathrm{FBC} 10$, enquanto alumínio foi maior na dieta FBC10 e menor na dieta FBC120 assim como os teores de cromo e chumbo foram maiores nos animais da dieta CAR10 e menores na dieta MBC60. Fontes alternativas de fósforo e baixas relações P:F aumentaram a deposição de minerais em ossos e fígado, sendo menor nos músculos.

Palavras-chave: cádmio, fígado, metais pesados, músculo, nutrição

\section{INTRODUCTION}

Alternative resources of phosphorus in relation to the bicalcium phosphate, usually employed in the rations and the mineral supplies, has been studied by nutrition researchers (TEIXEIRA et al., 2011). The Brazilian laws limit only the phosphorus concentration, without to consider the heavy metals and other contaminants (JUNQUEIRA, 1993). Phosphates employed in the agriculture, such as rock phosphate and triple superphosphate are not submitted to any control procedure regarding the fluorine levels, which can present contaminants, such as heavy metals.

The animal intoxication denotes a necessity of changes in the quality indicators. The market has elevated the levels of quality, requiring certification of high level of nutrition safety, following, for instance, the limit values in food resources to animals of National Research Council (NRC, 2005). Moreover, the Brazilian legislation has resources to guarantee the safety and the health of the population through the control of food residues (BRAZIL, 1999).

Contaminants in soil and food has generated discussions, due to the toxic effects in animal and human healths. For example, lung edemas, anemia and hypertension are symptoms associated to metal intoxications (ADAMS et al., 2004).

The problems originated by the mineral excessive ingestion are proeminents as function of the high levels of metals in the diet as well as the time interval of utilization of this diet. This kind of intoxication is cause of a series of perturbations of the organism that, in extreme cases, can be lethal. The deposition of metals in the animal organism depends on concentration of this metal in the source as well as the metabolic equilibrium of the other minerals salts that are absorbed (NRC, 2005). Cadmium and Lead were found in tissues of liver and kidney of different species of animals evaluated by Craig et al. (CRAIG, 1991), emphasizing the risk of accumulation these elements.

The substrates used in rations are submitted to quality control, but products that cause clinical alterations in species, such as the cattle, can be employed. It was observed testicular degeneration in bulls and accumulation in ovaries of cows, provoking the absence of estrus and changes in reproductive cycle (MARÇAL et al., 2001).

This work is focused on the chemical composition of phosphorus sources, including fluorine, and its influence upon the mineral deposition in tissues of cattle.

\section{MATERIAL AND METHODS}

The experiment was developed at Araçatuba, São Paulo State (SP), Brazil. The region of Araçatuba (SP) is characterized as a subtropical (Cfa) area, in agreement with Köppen classification, with raining summer, dry winter, with annual precipitation around 
$1245 \mathrm{~mm}$ (SISTEMA, 2006). The media of annual temperature oscillates between $15.8^{\circ} \mathrm{C}$ and $31.9^{\circ} \mathrm{C}$ (CIIAGRO, 2006).

It was analyzed a group of 49 nocastred male calves of the Nelore breed. The calves were weaned with initial age of 9 months and $230 \mathrm{~kg}$ of corporal weight. The post weaning calves obtained from a herd of 300 animals, after selection process with employment of a criterion of lower standard deviation of the herd to a variable weight.

The animals were distributed of randomized form in the respective treatments, compounding to a completely randomized design (CRD) with seven treatments (Table 1) and seven repetitions. The experimental unit was represented by the animal.

The animals were disposed in pens, which contained feeders and water drikers. These animals received complete mineral mixture, excepting phosphorus, which was furnished, ad libitum, in a specific feeder.

The phosphorus $(\mathrm{P})$ sources employed in the present work were commercial products that are available in the market and authorized by the Brazilian laws. These $\mathrm{P}$ sources were furnished in sufficient quantity to allow a diary ingestion of $4.5 \mathrm{~g}$ of phosphorus $(\mathrm{P})$ by day by animal. In order to become the $\mathrm{P}$ sources available to the animals through the dry matter intake, it was propitiated $0.250 \mathrm{~kg}$ of ground corn to be total and homogenously consumed.

Table 1 Chemical Composition of the phosphorus sources evaluated in the analysis

\begin{tabular}{llcccc}
\hline \multirow{2}{*}{ Treatments } & \multirow{2}{*}{ Phosphorus sources } & \multicolumn{3}{c}{ Chemical Composition of the Phosphorus Source } \\
\cline { 3 - 5 } & & $\mathrm{P}(\%)$ & $\mathrm{Ca}(\%)$ & $\mathrm{F}(\%)$ & Relation P:F \\
\hline CONT & $\quad----$ & 0 & 0 & 0 & 121 \\
FBC120 & Dicalcium phosphate & 18.1 & 24.0 & 0.15 & 64 \\
MBC60 & Monodicalcium phosphate & 20.5 & 20.1 & 0.32 & 30 \\
FBC30 & Dicalcium phosphate & 18.1 & 24.0 & 0.60 & 22 \\
SFT30 & Super Triple phosphate & 19.6 & 16.3 & 0.9 & 13 \\
FBC10 & Dicalcium phosphate & 18.1 & 24.0 & 1.4 & 8 \\
CAR10 & Phosphatic concentrated & 15.6 & 35.9 & 2 & \\
\hline
\end{tabular}

CONT $=$ Control diet; FBC120 $=$ Dicalcium phosphate 120:1 of relation P:F; MBC60 = Monodicalcium phosphate 60:1 of relation P:F; FBC30= Dicalcium phosphate 30:1 of relation P:F; SFT30 = Super triple phosphate $30: 1$ of relation P:F; $\mathrm{FBC} 10=$ Dicalcium phosphate 10:1 of relation P:F; CAR10= Concentrated of Apatite rock 10:1 of relation P:F.

The diet was composed by soybean hulls, hydrogenated fat, corn gluten meal, urea, hydrolyzed sugarcane bagasse, together with the $\mathrm{P}$ sources that are presently evaluated in this work (Table 2). The furnishment of the diet was propitiated ad libitum and in suitable quantity, being the ingestion adjusted through the evaluation of the excess that remained in the pen. These diet ingredients above mentioned were chosen due to their low levels of phosphorus, which would favor a more consistent analysis focused on the phosphorus deposition originated by the sources studied in the present work.

The diet was elaborated in order to generate weight gain of approximately $0.60 \mathrm{Kg}$ day $^{-1}$ for each animal, in agreement with NRC (1996). The complete diet was furnished to the animals at 8:00 and 16:00 hours in the 
same quantities. The sources that were the "test sources" were available only in the morning treatment, being disposed upon the ration with the objective of to guarantee the total ingestion by the individuals.

The period of experimentation was 927 days. It is important to notice that the great interval of time to experimentation does not any relationship with the productive potential of the animals and with the production system. This option was preferred in order to evaluate the effect of the biological accumulation in a significant interval of time, which is a characteristic phenomenon of heavy metals.

Table 2 Centesimal and Nutritional Composition of the Basic Ration

\begin{tabular}{lccccc}
\hline Ingredients & \% in the diet & $\mathrm{Pb}(\%)$ & $\mathrm{P} \mathrm{( \% )}$ & $\mathrm{Ca}(\%)$ & $\mathrm{F} \mathrm{( \% )}$ \\
\hline Soybean Hulls & 91.10 & 30.66 & 0.14 & 0.49 & 0.01 \\
Hydrogenated Fat & 4.44 & 0.82 & 0.06 & 9.00 & 0.01 \\
Corn Gluten meal & 1.12 & 65.29 & 0.44 & 0.12 & 0.06 \\
Urea & 3.34 & 281.00 & 0.00 & 0.00 & 0.00 \\
\hline Total & 100.00 & 38.30 & 0.14 & 0.85 & 0.01 \\
\hline Hydrolyzed Sugarcane Bagasse & ad libitum & 1.43 & 0.04 & 0.118 & 0.006 \\
\hline
\end{tabular}

In the final of the experimental period, after 18 hours of fasting weight, four animals for treatment were slaughtered. In the procedure of choose of the animals to the slaughter, it was preferred weights similar to the media of each treatment.

It was collected the phalanx of the right forelimb of the animals, which was stripped, degreased in Soxhlet extractor and submitted to the greenhouse of forced air circulation, in $65^{\circ} \mathrm{C}$ for 72 hours, being, subsequently, triturated in ball mill (ball roller). In this way, the definitive dry matter was obtained in greenhouse at $105^{\circ} \mathrm{C}$ for 24 hours.

It was collected and frozen samples of approximately 150 grams of liver (right lobe), kidney, heart and muscle (Longissimus dorci), in order to procedure posterior mineral analysis. After these samples to be conditioned to the environmental temperature, the sample was cut in small pieces, being submitted to the greenhouse of forced air circulation, at $65^{\circ} \mathrm{C}$ for 72 hours and, subsequently, triturated in ball mill. The definitive dry matter was determined in greenhouse at $105^{\circ} \mathrm{C}$ for 24 hours. The levels of ash were determined in muffle furnace at $600^{\circ} \mathrm{C}$.

One gram of the dried and grounded sample of the tissues was disposed in digestion tubes, adding $25 \mathrm{~mL}$ of nitropercloric solution (1:1). Subsequently, the tubes were conduced to the digester block, elevating slowly the temperature to $160^{\circ} \mathrm{C}$, until the sample losses its characteristic color. After cooling, the volumn was completed with distillated water.

The mineral levels in the tissues were determined through the atomic absorption spectroscopy; the phosphorus levels were identified by spectroscopy of absorption in the ultraviolet-visible region (UV-VIS spectroscopy), while the fluorine was analyzed by potentiometry (CBAA, 2009). All the chemical analyses were realized in the laboratory of Rodes Química Cajati Ltda., at Cajati, São Paulo state (SP), Brazil.

The parameters evaluated in the experiment were the mineral and heavy 
metal levels present in bones, heart, kidney, and muscles of bovines. It was developed the analysis of data variance, being that in case of statistic difference, it was compared the media of the treatments containing different additional phosphorus sources through the StudantNewman Keuls test, considering 5\% de significance. Similarly, the media of the treatments containing supplementary phosphorus sources were compared with the negative control treatment (CONT) by the Dunnett test $(\mathrm{P}>$ ou $<0,05)$.

\section{RESULTS AND DISCUSSION}

In Table 3, it was presented the chemical composition of the phosphorus sources that were evaluated in the present work. The level of lead $(\mathrm{Pb})$ was superior $(\mathrm{P}<0,05)$ in the CAR10 in relation to the other phosphorus sources. The levels of lead $(\mathrm{Pb})$ were also higher than those encountered by Lima et al. (1995), which worked with five types of dicalcium phosphate that are produced in Brazil and two ones that are produced in United States of America, in agreement with Teixeira et al. (2005). Teixeira et al. (2005) observed that monodicalcium phosphate, dicalcium phosphate and phosphoric acid presented low level of contamination by heavy metals. However, these authors identified also high levels of heavy metals between commercial products of super triple, super simple and in the phosphate rocks.

Table 3 Chemical Composition of Phosphorus sources evaluated in this work

\begin{tabular}{lcccccc}
\hline \multirow{2}{*}{ Minerals } & \multicolumn{7}{c}{ Treatments } \\
\cline { 2 - 6 } & FBC120 & MBC60 & FBC30 & SFT30 & FBC10 & CAR10 \\
\hline Phosphorus (\%) & 18.1 & 20.5 & 18.1 & 19.6 & 18.1 & 15.6 \\
Calcium (\%) & 24.0 & 20.1 & 24.0 & 16.3 & 24.0 & 35.9 \\
Fluorine (\%) & 0.15 & 0.32 & 0.60 & 0.9 & 1.4 & 2 \\
Magnesium (\%) & 1.74 & 1.07 & 1.74 & 0.30 & 1.74 & 0.30 \\
Iron (\%) & 0.23 & 0.19 & 0.23 & 0.89 & 0.23 & 1.64 \\
Aluminum (\%) & 0.10 & 0.07 & 0.10 & 0.08 & 0.10 & 0.13 \\
Manganese (ppm) & 301 & 162 & 301 & 195 & 301 & 813 \\
Zinc (ppm) & 17 & 12 & 17 & 43 & 17 & 205 \\
Copper (ppm) & 10 & 17 & 10 & 17 & 10 & 26 \\
Cobalt (ppm) & 11 & 10 & 11 & 10 & 11 & 17 \\
Cromium (ppm) & 7 & 5 & 7 & 16 & 7 & 28 \\
Cadmium (ppm) & 0.32 & 0.19 & 0.32 & 3.85 & 0.32 & 1.00 \\
Lead (ppm) & 1.74 & 2.74 & 1.74 & 1.54 & 1.74 & 3.00 \\
Vanadium (ppm) & 25 & 27 & 25 & 105 & 25 & 94
\end{tabular}

CONT $=$ Control diet; FBC120 = Dicalcium phosphate 120:1 of relation P:F; MBC60 = Monodicalcium phosphate $60: 1$ of relation P:F; FBC30 = Dicalcium phosphate 30:1 of relation P:F; SFT30 = Super triple phosphate $30: 1$ of relation P:F; FBC10 = Dicalcium phosphate 10:1 of relation P:F; CAR10= Concentrated of Apatite rock 10:1 of relation P:F.

The SFT30 that was analyzed in the present work contained $3.85 \mathrm{mg} / \mathrm{Kg}$ of cadmium $(\mathrm{Cd})$, which is an inferior value in comparison with the 14.15 $\mathrm{mg} / \mathrm{Kg}$ of $\mathrm{Cd}$ that was encountered by Teixeira et al. (2005). Probably, the 
STF30 was not produced with imported phosphate source, since the Brazilian rocks present low level of cadmium (LOPES et al., 1997).

The levels of Lead $(\mathrm{Pb})$ in the phosphorus sources analyzed varied from 1.54 until $3.00 \mathrm{mg} / \mathrm{kg}$, which corresponds to an inferior value range in comparison with the range of 12.6 until $48.5 \mathrm{mg} / \mathrm{kg}$ that was found by Teixeira et al. (TEIXEIRA, 2005), denoting lower contaminant presence. The sources of phosphorus with lower degree of processing, CAR10 e SFT30, obtained higher presence of these heavy metals.

It is important to emphasize the antagonism between the mineral nutrients, such as lead and cadmium, which are present in mineral supplies, since they can induce deficiency of essential mineral nutrients in the bovine diet, mainly the calcium (NRC, 1996). In fact, lead and cadmium have antagonic actions in relation to the zinc, which is an essential mineral to the metabolism of several enzymes. It is a specific constituent of the carbonic anhidrase, acting also as a supporting chemical component of aldolases, enolases, phosphatases, catalases, peptidases, between others, and being, therefore, involved with the proteic synthesis as well as the carbohydrate metabolism (NRC,1996).

This competition occurs between the supracited metals due, mainly, to the predominance of divalent cations to these elements, i.e., the oxidation state $2+$ is the preferential one of these metals in the biological medium. In fact, the oxidation state $2+$ is usual to cadmium, zinc and calcium, which is a alkaline earth metal (Family IIA) and to the Lead (in this last case, the divalent cation has high prevalence together with the oxidation state $4+$ (tetravalent cationic state). Therefore, there is a significant competition related to electrostatic interactions, involving the respective metallic cations, which act as acids of Lewis and compete mutually for a great number of "donor" sites that are present in several molecules in the biological medium (bases of Lewis). Thus, $\mathrm{Pb}^{2+}$ and $\mathrm{Cd}^{2+}$ can compete for the electronic pair "donor" sites, such as $\mathrm{Ca}^{2+}$ e $\mathrm{Zn}^{2+}$, which can generate a intrinsical risk of lead and/or cadmium intoxication and, concomitantly, provoke malnutrition related to essential metallic ions, such as $\mathrm{Ca}^{2+}$ and $\mathrm{Zn}^{2+}$, which can be dislocated from the "target sites" by toxic divalent cations.

It was observed significant effect related to the iron level in the bones of the bovines $(\mathrm{P}<0.05)$ (Table 4$)$. The iron value was higher in the animals that consumed the diet FBC10 $(\mathrm{P}<0.05)$. In the animals that consumed the diet MBC60, FBC30 and CAR10, intermediary values were founded $(\mathrm{P}>0.05)$, while in those feed with STF30 e FBC120, it was encountered the lower values $(\mathrm{P}<0.05)$.

The aluminum level was higher in the animals that consumed the diet denominated FBC10 $(\mathrm{P}<0.05)$ in relation to those that consumed CAR10, being that the individuals that consumed FBC30, MBC30, FBC120 and MBC60 obtained the lower level of aluminum in their bones $(\mathrm{P}<0.05)$.

Greenwood et al. (1964) demonstrated that there is a relationship between the utilization of sulfate of aluminum in the diet and the decrease of diseases caused by fluorine excess.

Aluminum is considered for various authors an inorganic chemical element of great risk to the health of the creation animals, mainly in the bovine species, which have an antagonism with the phosphorus, which is an essential element (ANDRIGUETTO et al., 1988). In fact, both elements have proximal atomic numbers (aluminum has atomic 
number 13 and phosphorus has atomic number 15 , being that these elements are inserted in the same period of the periodic table), implying that their atomic and ionic radius, depending of the oxidation states of both, can be proximal values. In this way, it would be chemically coherent, depending of the oxidation state of phosphorus, the occurrence of effective competition between both, in a species of "ionic exchange process".

Table 4 Mineral levels in the bovine bones feeded with different sources of phosphorus and fluorine levels

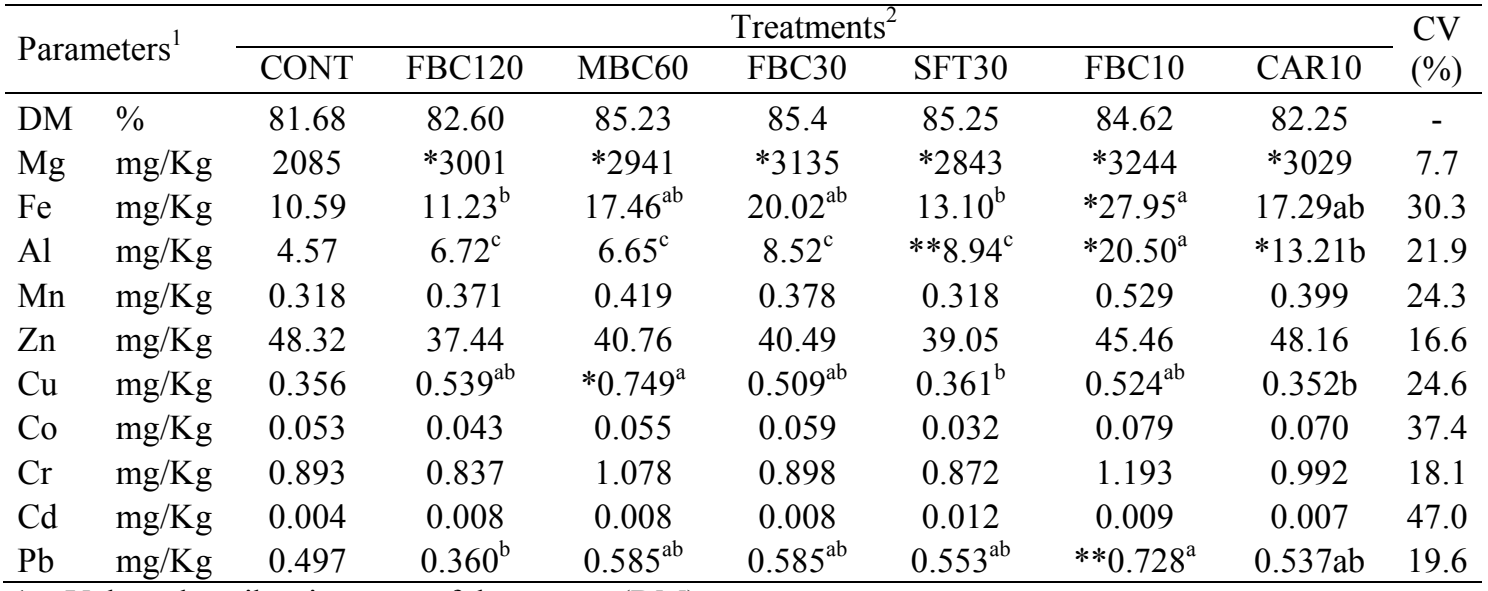

1 - Values describes in terms of dry matter (DM).

${ }^{1}(\mathrm{P}<0.05)$ Medium values and different symbols in the line, by the Student-Newman-Keuls test.

*Different medium values $(>$ ou $<$ ) in comparison with the CONT diet (negative control), by Dunnett test at $1 \%$.

**Different medium values $(>$ ou $<$ ) in comparison with the CONT diet (negative control), by Dunnett text at $5 \%$.

${ }^{2} \mathrm{CONT}=$ Control diet; FBC120 $=$ Dicalcium phosphate 120:1 of relation P:F; MBC60 = Monodicalcium phosphate $60: 1$ of relation P:F; FBC30 = Dicalcium phosphate 30:1 of relation P:F; SFT30 = Super Triple phosphate $30: 1$ of relation P:F; FBC10 = Dicalcium phosphate 10:1 of relation P:F; CAR10= Concentrated of Apatite rock 10:1 of relation P:F.

Aluminum can generate intoxication in bovines, mainly in young animals. These intoxications are frequently associated to the ingestion of contaminated feeds (MARÇAL et al., 2007), and can generate encephalopathy (CRAPPER \& TOMKO, 1995). Aluminum induces the deficiency of essential minerals to bovines, especially the calcium, when it is present in mineral supplies (NRC, 1996). Furthermore, it is important to reinforce that the aluminum antagonizes the zinc actions, which is an essential mineral to the metabolism of various enzymes (MARÇAL et al., 2001). Indeed, it is comprehensible that aluminum generated an effective competition with calcium and zinc. The more usual oxidation states to the aluminum are +1 and mainly +3 , which becomes the aluminum cations relatively "hard" ions, in agreement with the acid-base concept of Pearson. In this context, the competition with the calcium cations (alkaline earth metal), $\left(\mathrm{Ca}^{2+}\right)$, and zinc, which has also the oxidation state $2+$ as prevalent redox state, would present high probability to occur, especially if the aluminum cations are in biological medium with significant concentration. 
Animals that consumed the CONT diet have lower value of magnesium $(\mathrm{P}<0,05)$ in comparison with those that consumed the other diets presently evaluated.

The bones contain 2 grams of Manganese $(\mathrm{Mg})$ for Kilogram $(\mathrm{Kg})$ of fresh material and the relation $\mathrm{Ca}: \mathrm{Mg}$ is $55: 1$, being that $70 \%$ of the Manganese that are present in the body are situated in the bones. For its time, the muscle tissue contains $190 \mathrm{mg}$ to $\mathrm{mg} / \mathrm{Kg}$ (COELHO DA SILVA, 1995), while $1 \%$ is associated to the extracellular enviroments (CSIRO, 1990).

The level of copper was higher $(\mathrm{P}<0.05)$ in the animals that consumed the MBC60 diet, while the diets called FBC120, FBC30 and FBC10 obtained intermediary values $(\mathrm{P}>0.05)$. STF30 and CAR10 presented the lower value $(\mathrm{P}<0.05)$.

The level of lead was higher $(\mathrm{P}<0,05)$ in the animals that ingested the FBC 10 diet, being that the diets denominated MBC60, FBC30, SFT30 and CAR10 obtained intermediary values $(\mathrm{P}>0,05)$ and FBC120 obtained the lower value $(\mathrm{P}<0.05)$.

In agreement with Borges (1991), there are several relations between phosphorus and other mineral ions, which can difficult the availability of phosphorus to the animals. Frequently, elements as iron, aluminum, manganese, magnesium and heavy metals can decrease the phosphorus absorption due to the formation of insoluble phosphate. Furthermore, the great variability of possible oxidation states to phosphorus implies that various ionic competitions can occur. These competitions, which are related to the electrostatic charge of each ion as well as the ionic radius of the anions and cations is quite dependent of the oxidation state presented by phosphorus. Similarly, the great variability of chemical environments around the phosphorus compounds in the biological medium modifies significantly the electronic densities that each compound can present, even being in a same oxidation state. Consequently, this great variability of electronic density tends to affect intensely the chemical reactivity and the possibility of ionic interaction with various biomolecules.

Only wide comparisons can be elaborated between the results of the present study and the data related in literature, because there is a significant variation between these respective studies, considering their medium values, the detection limits and the valued assigned to low concentrations. Furthermore, the age of the animals is also an important factor of bioaccumulation of metals, such as the cadmium.

Considering the additional sources of phosphorus evaluated in the present work, it was possible to observe that the relation phosphorus:fluorine $(\mathrm{P}<0,05)$ affected the levels of $\mathrm{Mg}, \mathrm{Al}, \mathrm{Cr}, \mathrm{Cd}$ and $\mathrm{Pb}$ encountered in the liver of the animals (Table 5). It is coherent with the fact of the fluorine to occur in the biological medium as monovalent anion (1), being characterized as a significantly "hard" Lewis base, in agreement with the Pearson acid-base concept. Therefore, this ion presents high charge/radius relationship and can compete with the phosphorus by "hard" or "bordeline" Lewis acids. Usually, magnesium, aluminum, and chromium occur as relatively "hard" cations ( $\mathrm{Mg}(\mathrm{II})$; $\mathrm{Al}(\mathrm{I})$ or $\mathrm{Al}(\mathrm{III})$; and $\mathrm{Cr}(\mathrm{III})$. In fact, the chromium presents high redox variability, but demonstrates significant prevalence of $\mathrm{Cr}$ (III) in the biological medium. The cadmium $(\mathrm{Cd})$ frequently takes place as a "borderline" cation $(\mathrm{Cd}(\mathrm{II}))$ and the lead $(\mathrm{Pb})$ can occur as "borderline" ( $\mathrm{Pb}(\mathrm{IV})$ or "soft" one 
( $\mathrm{Pb}(\mathrm{II}))$.

The magnesium level was higher in the animals that consumed the FBC30 diet, while the diets that are called FBC120, SFT30, FBC10 and CAR10 obtained intermediary values and MBC60 presented a lower value $(\mathrm{P}<0.05)$.

The level of aluminum was lower $(\mathrm{P}<0.05)$ in the animals that ingested the diet MBC60, being that the diets FBC30 and CAR10 obtained intermediary values and the diets SFT30, FBC10 and FBC120 generated the higher value.

The levels of cadmium and lead were higher in the animals that consumed the diet STF30 $(\mathrm{P}<0.05)$. The moderated ingestion of cadmium by the animals can cause anemia; loses of the bones mineralization and liver lesions (NRC, 2005). In agreement with Brazil (1999), it was observed, in the liver of the animals, that the tolerance limits of $2 \mathrm{mg} / \mathrm{Kg}$ to the lead and $1 \mathrm{mg} / \mathrm{Kg}$ to cadmium were extrapolated. In fact, in the biological medium, mainly in vascularized tissues, the number of Lewis bases, classified by Pearson as "hard" and "borderline" bases are significantly elevated, favoring the fixation of the above mentioned metals in tissues with high metabolic relevance, like, for instance, is the case of the liver tissue.

Table 5 Minerals in the liver of bovines feed with different phosphorus source and levels of fluorine

\begin{tabular}{llcccccccc}
\hline \multirow{2}{*}{ Parameters } & & \multicolumn{9}{c}{ Treatments $^{1}$} & CV \\
& & CONT & FBC120 & MBC60 & FBC30 & SFT30 & FBC10 & CAR10 & $(\%)$ \\
\hline MS & $\%$ & 28.35 & 29.32 & 29.51 & 28.93 & 28.70 & 29.24 & 28.41 & - \\
Ash & $\%$ & 5.57 & 5.51 & 4.98 & 5.09 & 5.26 & 5.05 & 5.59 & 9.8 \\
Total P & $\%$ & 1.29 & 1.28 & 1.36 & 1.33 & 1.36 & 1.30 & 1.31 & 4.3 \\
Calcium & $\%$ & 0.030 & 0.033 & 0.024 & 0.028 & 0.029 & 0.030 & 0.023 & 17.4 \\
Fluor & $\mathrm{mg} / \mathrm{Kg}$ & 28.60 & 43.64 & 39.39 & 36.44 & 40.96 & 37.47 & 28.26 & 27.4 \\
Magnesium & $\mathrm{mg} / \mathrm{Kg}$ & 559 & $558^{\mathrm{ab}}$ & $521^{\mathrm{b}}$ & $613^{\mathrm{a}}$ & $515^{\mathrm{ab}}$ & $573^{\mathrm{ab}}$ & $468^{\mathrm{ab}}$ & 18.6 \\
Iron & $\mathrm{mg} / \mathrm{Kg}$ & 742 & 516 & 419 & 542 & 727 & 566 & 503 & 45.5 \\
Aluminum & $\mathrm{mg} / \mathrm{Kg}$ & 70.2 & $73.2^{\mathrm{a}}$ & $* 26.4^{\mathrm{b}}$ & $56.3^{\mathrm{ab}}$ & $73.8^{\mathrm{a}}$ & $73.5^{\mathrm{a}}$ & $52.3^{\mathrm{ab}}$ & 29.4 \\
Manganese & $\mathrm{mg} / \mathrm{Kg}$ & 6.71 & 7.62 & 6.15 & 8.66 & 6.71 & 7.43 & 6.53 & 15.1 \\
Zinc & $\mathrm{mg} / \mathrm{Kg}$ & 508 & $* * 110$ & 287 & 403 & 324 & 208 & 522 & 55.6 \\
Copper & $\mathrm{mg} / \mathrm{Kg}$ & 394 & 432 & 446 & 677 & 542 & 521 & 484 & 29.8 \\
Cobalt & $\mathrm{mg} / \mathrm{Kg}$ & 1.07 & 0.74 & 0.88 & 1.14 & 0.54 & 0.85 & 1.05 & 32.8 \\
Cromium & $\mathrm{mg} / \mathrm{Kg}$ & 2.407 & 1.572 & 3.023 & 2.825 & 2.104 & $* * 3.741$ & 3.098 & 21.7 \\
Cadmium & $\mathrm{mg} / \mathrm{Kg}$ & 0.140 & $0.141^{\mathrm{b}}$ & $0.115^{\mathrm{b}}$ & $0.140^{\mathrm{b}}$ & $0.217^{\mathrm{a}}$ & $0.140^{\mathrm{b}}$ & $0.155^{\mathrm{b}}$ & 29.1 \\
Lead & $\mathrm{mg} / \mathrm{Kg}$ & 0.298 & $0.410^{\mathrm{ab}}$ & $0.222^{\mathrm{b}}$ & $0.238^{\mathrm{b}}$ & $0.651^{\mathrm{a}}$ & $0.206^{\mathrm{b}}$ & $0.396^{\mathrm{ab}}$ & 59.2 \\
\hline
\end{tabular}

1 Values described in terms of Dry Matter (DM).

${ }^{1}(\mathrm{P}<0.05)$ Medium values and distinct symbols in the line are mutually different by the Student-NewmanKeuls test.

*Different medium values $(>$ ou $<$ ) in comparison with the CONT diet (negative control), by Dunnett test at $1 \%$.

**Different medium values $(>$ ou $<$ ) in comparison with the CONT diet (negative control), by Dunnett test at $5 \%$.

${ }^{2} \mathrm{CONT}=$ Control diet; FBC120 $=$ Dicalcium phosphate 120:1 of relation P:F; MBC60 = Monodicalcium phosphate $60: 1$ of relation P:F; FBC30 = Dicalcium phosphate 30:1 of relation P:F; SFT30 = Super Triple phosphate $30: 1$ of relation P:F; FBC10 = Dicalcium phosphate 10:1 of relation P:F; CAR10= Concentrated of Apatite rock 10:1 of relation P:F. 
The mineral deposition in the animal organism does not depend exclusively of the source concentration, but also of the metabolic equilibrium of the other minerals that are absorbed (NRC, 2005). Probably, the high levels of cadmium found in the super triple phosphate composition were deposited in the bovine liver. Swines that consumed diets containing super triple phosphate presented high levels of cadmium in the liver (TEIXEIRA et al., 2005).

Heavy metals present, as local of metabolism and maximum deposition, the liver (TEIXEIRA et al., 2005). This organ has its activity increased in the more intense physiological processes, such as weight gain, reproductive activity, pregnancy and stress conditions. Therefore, in several situations of great relevance in animal science, the accumulus of heavy metals in liver tends to be accentuated. Eggs, meat and milk can present heavy metals, being their concentrations proportional to the ingestion (SHIRLEY, 1985).

In the years 2006 and 2008, the European Union established maximum limits of cadmium in feed (in the base of the natural matter), of animal origin, being bovine meat, (excepting offal) as liver with $0.50 \mathrm{mg} \mathrm{Kg}^{-1}$ and kidney with $1.0 \mathrm{mg} \mathrm{Kg}^{-1}$ (Rules (EU) ${ }^{\circ} 629 / 2008$ and (EU) $\left.n^{\circ} 1881 / 2006\right)$.

Considering the samples of liver analyzed in the present work, there was not identified any concentration above of the quantification limit, with value of $23 \mu \mathrm{g} \mathrm{kg}^{-1}$ (Table 5), which demonstrates the low concentration of cadmium in the meat produced in the conditions of the respective experiment. Nomura \& Oliveira (2006), studying samples of bovine liver obtained in butcher shops of São Paulo city, encountered levels around $70 \mu \mathrm{g} \mathrm{kg}^{-1}$ of cadmium Therefore, we can consider that the diets employed in the present study are interesting nutritional alternatives aiming the decrease of drastic intoxications by cadmium in the Brazilian bovine livestock.

The phosphorus sources and the relations $\mathrm{P}: \mathrm{F}$ were not associated to any modification $(\mathrm{P}>0,05)$ in the levels of phosphorus and fluorine of bovine heart and muscles (Tables 6 and 7).

Usually, the "soft tissues" and fluids are not associated to accumulation of fluorine, even in conditions of elevated ingestion of this element. However, tendon, aorta and placenta presents higher fluorine concentration when compared with other "soft tissues" (NRC, 2005), which can be associated to the relatively high levels of calcium and magnesium that are two "hard" divalent Lewis bases, in agreement with Pearson Classification. This process is related to the high chemical affinity between the endogenous interaction sites and the fluorine anion $\left(\mathrm{F}^{-}\right)$, which is a highly "hard" base.

The level of chromium was higher $(\mathrm{P}<0,05)$ in the animals that consumed the diets CAR10 and STF30, being that the dies FBC120 and FBC30 obtained intermediary values $(\mathrm{P}>0,05)$, while MBC60 and FBC10 presented the lower value $(\mathrm{P}<0,05)$ (Table 6$)$.

In the bovine hearts, the levels of $\mathrm{Mg}$, $\mathrm{Mn}, \mathrm{Cr}$ e Cd were affected $(\mathrm{P}<0,05)$ by the diet composition (Table 7). The level of aluminum was higher in the animals that consumed the CAR10 diet in comparison with those that ingested the other diets.

The higher levels of cadmium in the heart of animals that ingested CAT10 diet suggests that the cadmium excess in the respective source was accumulated in the heart. In agreement with the levels proposed by Brazil (1999), it was not identified sample with heavy metals level above of the tolerance limit. 
Table 6 Minerals in the muscle tissues of bovines feed with different phosphorus and fluorine sources

\begin{tabular}{|c|c|c|c|c|c|c|c|c|c|}
\hline \multirow{2}{*}{ Parameters } & & \multicolumn{7}{|c|}{ Treatments $^{1}$} & \multirow{2}{*}{$\begin{array}{l}\mathrm{CV} \\
(\%)\end{array}$} \\
\hline & & CONT & FBC120 & MBC60 & FBC30 & SFT30 & FBC 10 & CAR10 & \\
\hline DM & $\%$ & 30.49 & 32.43 & 31.31 & 29.03 & 31.89 & 30.41 & 32.08 & - \\
\hline Ash & $\%$ & 3.670 & 3.326 & 3.638 & 4.130 & 3.618 & 3.715 & 3.516 & 21.4 \\
\hline P total & $\%$ & 0.697 & 0.577 & 0.686 & 0.797 & 0.686 & 0.693 & 0.646 & 14.1 \\
\hline Calcium & $\%$ & 0.018 & 0.021 & 0.020 & 0.021 & 0.015 & 0.016 & 0.019 & 28.9 \\
\hline Fuorine & $\mathrm{mg} / \mathrm{Kg}$ & 30.03 & 28.48 & 30.28 & 31.79 & 30.83 & 32.83 & 29.84 & 22.8 \\
\hline Magnesium & $\mathrm{mg} / \mathrm{Kg}$ & 518 & 591 & 604 & 703 & 538 & 554 & 473 & 36.3 \\
\hline Iron & $\mathrm{mg} / \mathrm{Kg}$ & 59.26 & 63.09 & 60.22 & 77.86 & 54.73 & 64.20 & 54.81 & 36.8 \\
\hline Aluminun & $\mathrm{mg} / \mathrm{Kg}$ & 9.693 & 14.114 & 11.679 & 13.813 & 12.781 & 11.035 & 13.258 & 34.3 \\
\hline Manganese & $\mathrm{mg} / \mathrm{Kg}$ & 0.504 & 0.343 & 0.477 & 0.562 & 0.436 & 0.409 & 0.490 & 48.2 \\
\hline Zinc & $\mathrm{mg} / \mathrm{Kg}$ & 129.36 & 186.08 & 109.36 & 130.72 & 200.09 & 119.61 & 192.39 & 53.9 \\
\hline Copper & $\mathrm{mg} / \mathrm{Kg}$ & 2.620 & 1.902 & 2.711 & 2.807 & 1.638 & 2.829 & 1.736 & 54.7 \\
\hline Cobalt & $\mathrm{mg} / \mathrm{Kg}$ & 0.058 & 0.108 & 0.137 & 0.103 & 0.084 & 0.076 & 0.079 & 56.6 \\
\hline Chromium & $\mathrm{mg} / \mathrm{Kg}$ & 0.685 & $0.711^{\mathrm{ab}}$ & $0.374^{\mathrm{b}}$ & $0.722^{\mathrm{ab}}$ & $1.266^{\mathrm{a}}$ & $0.346^{\mathrm{b}}$ & $1.287^{\mathrm{a}}$ & 50.4 \\
\hline Cadmium & $\mathrm{mg} / \mathrm{Kg}$ & 0.019 & 0.003 & 0.032 & 0.016 & 0.012 & 0.027 & 0.026 & 89.7 \\
\hline Lead & $\mathrm{mg} / \mathrm{Kg}$ & 0.255 & 0.161 & 0.264 & 0.233 & 0.318 & 0.249 & 0.323 & 47.0 \\
\hline
\end{tabular}

1 - Values described in terms of Dry Matter (DM).

${ }^{1}(\mathrm{P}<0.05)$ Medium values and distinct symbols in the line that are mutually different, by Student-Newman-Keuls test.

*Different medium values $(>$ ou $<$ ) in relation with the CONT diet (negative control), by Dunnett test at $1 \%$.

**Different medium values $(>$ ou $<$ ) in relation with the CONT diet (negative control), by Dunnett test at $5 \%$.

${ }^{2} \mathrm{CONT}=$ Control diet; FBC120 $=$ Dicalcium phosphate 120:1 of relation P:F; MBC60 = Monodicalcium phosphate $60: 1$ of relation P:F; FBC30 = Dicalcium phosphate 30:1 of relation P:F; SFT30 = Super Triple phosphate 30:1 of relation P:F; FBC10 = Dicalcium phosphate 10:1 of relation P:F; CAR10 = Concentrated of Apatite rock 10:1 of relation P:F. 
Table 7 Minerals in the heart of bovines feed with different phosphorus and fluorine sources

\begin{tabular}{|c|c|c|c|c|c|c|c|c|c|}
\hline \multirow{2}{*}{ Parameters } & & \multicolumn{7}{|c|}{ Treatments $^{1}$} & \multirow{2}{*}{$\begin{array}{l}\mathrm{CV} \\
(\%)\end{array}$} \\
\hline & & CONT & FBC 120 & MBC60 & FBC30 & SFT30 & FBC10 & CAR10 & \\
\hline DM & $\%$ & 23.57 & 23.44 & 22.46 & 23.03 & 23.76 & 24.08 & 24.90 & - \\
\hline Ash & $\%$ & 5.688 & 4.929 & 5.425 & 5.364 & 4.683 & 5.315 & 5.819 & 10.41 \\
\hline P total & $\%$ & 1.011 & 1.023 & 1.017 & 0.988 & 0.978 & 0.987 & 0.972 & 7.18 \\
\hline Calcium & $\%$ & 0.032 & 0.033 & 0.032 & 0.031 & 0.028 & 0.031 & 0.027 & 16.86 \\
\hline Fluorine & $\mathrm{mg} / \mathrm{Kg}$ & 34.11 & 49.87 & 48.35 & 52.08 & 43.04 & 48.34 & 34.76 & 21.10 \\
\hline Magnesium & $\mathrm{mg} / \mathrm{Kg}$ & 840.8 & $897.3^{\mathrm{a}}$ & $749.6^{\mathrm{ab}}$ & $690.0^{\mathrm{ab}}$ & $854.4^{\mathrm{a}}$ & $* 589.2^{\mathrm{b}}$ & $696.4^{\mathrm{ab}}$ & 12.33 \\
\hline Iron & $\mathrm{mg} / \mathrm{Kg}$ & 225.6 & 268.6 & 195.4 & 190.0 & 209.9 & 246.2 & 207.8 & 10.53 \\
\hline Aluminum & $\mathrm{mg} / \mathrm{Kg}$ & 8.767 & 12.084 & 8.261 & 10.971 & 7.495 & 8.071 & 10.168 & 29.38 \\
\hline Manganese & $\mathrm{mg} / \mathrm{Kg}$ & 2,088 & $2.203^{\mathrm{ab}}$ & $2.256^{\mathrm{ab}}$ & $* 1.519^{c}$ & $2.073^{b}$ & $* 2.575^{\mathrm{a}}$ & $2.368^{b}$ & 6.66 \\
\hline Zinc & $\mathrm{mg} / \mathrm{Kg}$ & 90.84 & 101.06 & 92.94 & 124.21 & 160.13 & $* * 189.23$ & 78.05 & 40.67 \\
\hline Copper & $\mathrm{mg} / \mathrm{Kg}$ & 29.06 & 19.31 & 25.27 & 33.09 & 27.06 & 30.91 & 26.85 & 43.10 \\
\hline Chromium & $\mathrm{mg} / \mathrm{Kg}$ & 0.331 & $0.152^{b}$ & $* * 1.310^{\mathrm{a}}$ & $0.696^{\mathrm{ab}}$ & $0.619^{\mathrm{ab}}$ & $* * 1.287^{\mathrm{a}}$ & $0.713^{\mathrm{ab}}$ & 56.29 \\
\hline Cadmium & $\mathrm{mg} / \mathrm{Kg}$ & 0.040 & $0.023^{b}$ & $0.039^{\mathrm{b}}$ & $0.044^{\mathrm{b}}$ & $0.026^{\mathrm{b}}$ & $0.031^{\mathrm{b}}$ & $* 0.083^{\mathrm{a}}$ & 25.33 \\
\hline Lead & $\mathrm{mg} / \mathrm{Kg}$ & 0.293 & 0.190 & 0.266 & 0.249 & 0.335 & 0.361 & 0.580 & 51.63 \\
\hline
\end{tabular}

1 - Values described in terms of Dry Matter (DM)

$1(\mathrm{P}<0.05)$ Medium values and distinct symbols in line that are mutually different, by Student-Newman-Keuls test

*Different medium values $(>$ ou $<$ ) in relation to the CONT diet (negative control), by Dunnett test at $1 \%$

$* *$ Different medium values $(>\mathrm{ou}<$ ) in relation to the CONT diet (negative control), by Dunnett test at $5 \%$

${ }^{2} \mathrm{CONT}=$ Control diet; $\mathrm{FBC} 120=$ Dicalcium phosphate 120:1 of relation P:F; MBC60 = Monodicalcium phosphate $60: 1$ of relation P:F; FBC30 = Dicalcium phosphate 30:1 of relation P:F; SFT30 = Super Triple phosphate 30:1 of relation P:F; FBC10 = Dicalcium phosphate 10:1 of relation P:F; CAR10 = Concentrated of Apatite rock 10:1 of relation P:F. 
Lopes et al. (2000), studying beef cattle, concluded that the mineral mixture that presents super triple phosphate produced from Tapira rock or the dicalcium phosphate does not offer risk to the human and/or animal health, concerning to the presence of heavy metals in the muscle masses.

Considering the cadmium values obtained in the present work, which were founded lower than the limits established to the kidney, it is possible to infer that the respective meat is suitable to the human nutrition, since this organ is the principal focus of deposition of cadmium in the human organism (BERTRAND et al., 1981; GARCÍA-FERNÁNDEZ et al., 1996).

It was not founded any violations in the meat sample analyzed in this work. This result is coherent with the tradition of kidney analysis in bovines in Brazil, which has been published by the Brazilian Ministery of Agriculture, Livestoke and Supply (which is wellknown as MAPA) through the PNCRC. Indeed, the violations related to cadmium in bovine kidneys are annually published in the "Official Diary of the Union" (vide site of MAPA). It is interesting to mention that the percentage of violation in the last year was $0.97 \%$ (BRAZIL, 2011).

In kidneys, the levels of $\mathrm{P}, \mathrm{Al}, \mathrm{Cr}$ and $\mathrm{Pb}$ were affected $(\mathrm{P}<0.05)$ by the diet composition. The level of phosphorus was higher $(\mathrm{P}<0.05)$ in the animals that consumed the diet CAR10 and lower in those that ingested the diet FBC10. The content of aluminum was higher $(\mathrm{P}<0.05)$ in the animals that consumed the diet $\mathrm{FBC} 10$ and lower in the animals that ingested the diet FBC120. The contents of chromium and lead were higher $(\mathrm{P}<0.05)$ in the animals that ingested the diet CAR10 and lower in the individuals that consumed the diet MBC60 (Table 8).
The absorption of cadmium in bovines is usually lower than $16 \%$, depending of the dose (HOOSER, 2007). The ingestion of cadmium until approximately $\quad 0.5 \mathrm{mg} \quad \mathrm{Kg}^{-1} \quad \mathrm{day}^{-1}$ consists in suitable nutrition, without originate significant risk to the health, since it is not generated representative bioaccumulation (BERTRAND et al., 1981).

The results obtained in the analysis of liver and kidney are in agreement with the data of literature, which indicate the kidney as principal biological organ of accumulation of cadmium (approximately half of the cadmium encountered in the body) (PHILLIPS, 2004). The cadmium, after absorbed in the intestine, is bounded to the albumine of plasm, forming proteic complexes in the liver. Therefore, the metallic cation of cadmium acts as a coordination center (metallic center) to the Lewis bases (Ligands) encountered in the residues of aminoacids of the proteins, which act in electronic pair donor sites and act as ligands, generating, coordination compounds, also called metallic complexes. These complexes are excreted by kidneys and through the endocytosis phenomenon occurs the liberation of cadmium ions of the metallic complexes previously formed. Thus, the cadmium cations are absorbed by the cells of the proximal tubules, making this area of the kidney cortex susceptible to the injuries and necrosis (HOOSER, 2007). It is well known that many farm animals consume diets that do not match their requirements in relation to minerals. The feed most commonly consumed by these animals contain unbalanced proportions with deficiency or excess of these elements, causing serious metabolic disorders (MENDONÇA JÚNIOR, 2011). This topic related to the fixation of heavy metals in ruminant biological tissues constitutes highly relevant 
subject, which has motivated studies focused on the evaluation of the concentration of heavy metals in different biological fluids and tissues as consequence of the presence of steel mills in a determined area (SOUZA, 2009). This context allows to infer that this topic should be considered in environment monitoring programs (SOUZA, 2009).

Table 8 Levels of mineral in the kidney of bovines feed with different sources of phosphorus and levels of fluorine

\begin{tabular}{llcccccccc}
\hline \multirow{2}{*}{ Parameters } & \multicolumn{7}{c}{ Treatments } & CV \\
\cline { 3 - 8 } & & CONT & FBC120 & MBC60 & FBC30 & SFT30 & FBC10 & CAR10 & $(\%)$ \\
\hline $\mathrm{DM}$ & $\%$ & 21.29 & 21.27 & 21.74 & 21.43 & 21.67 & 21.51 & 21.68 & - \\
Ash & $\%$ & 6.697 & $6.524^{\mathrm{ab}}$ & $6.049^{\mathrm{b}}$ & $6.637^{\mathrm{ab}}$ & $6.831^{\mathrm{ab}}$ & $7.179^{\mathrm{a}}$ & $6.464^{\mathrm{ab}}$ & 6.69 \\
Total P & $\%$ & 1.199 & $1.181^{\mathrm{ab}}$ & $1.228^{\mathrm{ab}}$ & $1.248^{\mathrm{ab}}$ & $1.220^{\mathrm{ab}}$ & $1.139^{\mathrm{b}}$ & $1.276^{\mathrm{a}}$ & 4.43 \\
$\mathrm{Ca}$ & $\%$ & 0.052 & 0.050 & 0.052 & 0.031 & 0.044 & 0.055 & 0.046 & 25.24 \\
$\mathrm{~F}$ & $\mathrm{mg} / \mathrm{Kg}$ & 38.794 & 42.871 & 40.791 & 46.458 & 39.067 & 47.335 & 47.678 & 30.37 \\
$\mathrm{Mg}$ & $\mathrm{mg} / \mathrm{Kg}$ & 783.022 & 629.999 & 762.848 & 622.589 & 565.859 & 738.691 & 656.096 & 20.46 \\
$\mathrm{Fe}$ & $\mathrm{mg} / \mathrm{Kg}$ & 549.481 & 607.779 & 526.678 & 522.352 & 434.397 & 692.393 & 545.023 & 21.95 \\
$\mathrm{Al}$ & $\mathrm{mg} / \mathrm{Kg}$ & 9.630 & $7.439^{\mathrm{d}}$ & $11.376^{\mathrm{bc}}$ & $8.995^{\mathrm{cd}}$ & $8.744^{\mathrm{cd}}$ & $* 16.030^{\mathrm{a}}$ & $* * 12.791^{\mathrm{b}}$ & 14.50 \\
$\mathrm{Mn}$ & $\mathrm{mg} / \mathrm{Kg}$ & 4.634 & 4.349 & 4.317 & 3.647 & 3.731 & 4.200 & 3.375 & 18.70 \\
$\mathrm{Zn}$ & $\mathrm{mg} / \mathrm{Kg}$ & 134.915 & 97.451 & 113.324 & 135.589 & 108.826 & 148.041 & 140.838 & 40.37 \\
$\mathrm{Cu}$ & $\mathrm{mg} / \mathrm{Kg}$ & 11.326 & 12.956 & 14.475 & 15.611 & 12.869 & 15.876 & 16.890 & 22.73 \\
$\mathrm{Cr}$ & $\mathrm{mg} / \mathrm{Kg}$ & 2.406 & $* * 1.327^{\mathrm{bc}}$ & $0.787^{\mathrm{c}}$ & $1.444^{\mathrm{bc}}$ & $2.256^{\mathrm{ab}}$ & $1.716^{\mathrm{abc}}$ & $2.611^{\mathrm{a}}$ & 29.81 \\
$\mathrm{Cd}$ & $\mathrm{mg} / \mathrm{Kg}$ & 0.651 & 1.030 & 0.917 & 0.948 & 0.807 & 1.013 & 1.262 & 38.64 \\
$\mathrm{~Pb}$ & $\mathrm{mg} / \mathrm{Kg}$ & 0.977 & $0.691^{\mathrm{ab}}$ & $0.629^{\mathrm{b}}$ & $1.006^{\mathrm{ab}}$ & $0.881^{\mathrm{ab}}$ & $0.961^{\mathrm{ab}}$ & $1.193^{\mathrm{a}}$ & 24.67 \\
\hline
\end{tabular}

1 - Values described in terms of Dry Matter (DM)

${ }^{1}(\mathrm{P}<0.05)$ Medium values and distinct symbols in line that are mutually different, by Student-Newman-

Keuls tests.

*Different medium values $(>\mathrm{ou}<$ ) in relation to the CONT diet (negative control), by Dunnett test at $1 \%$

**Different medium values ( $>$ ou $<$ ) in relation to the CONT diet (negative control), by Dunnett test at $5 \%$

${ }^{2} \mathrm{CONT}=$ Control diet; FBC120 $=$ Dicalcium phosphate 120:1 of relation P:F; MBC60 = Monodicalcium phosphate $60: 1$ of relation P:F; FBC30 = Dicalcium phosphate 30:1 of relation P:F; SFT30 = Super Triple phosphate $30: 1$ of relation P:F; FBC10 = Dicalcium phosphate 10:1 of relation P:F; CAR10= Concentrated of Apatite rock 10:1 of relation P:F.

Therefore, it is necessary a more specific application of the knowledge regarding the quantity of each mineral salt in the ruminant nutrition. Indeed, the role of the metals to the animal nutrition and production is decisive in all steps of this process, from the absorption mechanism, in agreement with previous work (MOREIRA, 2013), until the final deposition in the biological tissues, which is demonstrated in the present article. In this way, new perspectives to the understanding of the effective function of metallic ions in the animal nutrition and production can be inferred and more efforts could be directed on this topic.

Diets that contain inorganic sources of phosphorus and low relations phosphorus:fluorine tends to provoke deposition of these minerals in biological tissues, such as, bones and liver, being this deposition less intense in the muscles of the bovine carcass. 


\section{REFERENCES}

ADAMS, M.L.;ZHAO,F.J.;McGRATH, S.P.; NICHOLSON, F.A.;CHAMBERS, B.J. Predicting Cadmium concentrations in wheat and barley grain using soil properties. Journal of Environmental Quality, v.33, p.532 541, 2004.

ANDRIGUETO, J.M.; PERLY, L.; MINARDI, I.; GEMAEL, A.; FLEMMING, J.S.; SOUZA, G.A; BONA FILHO, A. Nutrição Animal. 4a.ed. São Paulo: Nobel, 1988. 395p.

BERTRAND, J.E.; LUTRICK, M.C.; EDDS, G.T.; WEST, R.L. Metal residues in tissues, animal performance and carcass quality with beef steers grazing Pensacola bahiagrass pastures treated with liquid digested sludge. Journal of Animal Science, v.53, p.146-153, 1981.

\section{BORGES, F.M.O. Utilização do} fósforo disponível de dez fontes de fósforo para frangos de corte. 56p. Dissertação (Mestrado em Zootecnia) Universidade Federal de Minas Gerais, Belo Horizonte, 1991.

BRAZIL. Ministery of Agriculture. Normative instruction $n^{\mathbf{0}} \mathbf{3}$, January 22 1999. Reediting the PNCRB, altering the rules regarding the control of beef residues. Brasília, Jan. 1999.

BRAZIL. Ministery of Health. Portaria n' 518, de 25 de março de 2004. Establishing the procedures and responsabilities regarding the control and vigilance of the water quality to the human nutrition and its potability standard and furnishing measurements, Brasília, 2011.
BRAZILIAN COMPENDIUM OF ANIMAL ALIMENTATION - CBAA. Guide of analytical methods. 2009. $217 p$.

COELHO DA SILVA, J.F. Demands of inorganic macroelements to bovines: The system ARC/AFRC and the experience in Brazil. In: INTERNATIONAL SYMPOSIUM ABOUT NUTRITIONAL DEMANDS OF RUMINANTS, 1995, Viçosa, MG. Annals ... Viçosa, MG, 1995. p.467504.

CRAIG, D.C.S.; CHAN, W.; SASCHENBRECKER, P.W. Multielement concentrations in liver and kidney tissues from five species of canadian slaughter animals. Journal of Association of Official Analytical Chemists, v.74, n.4, p.587-591, 1991.

CRAPPER, D.R.; TOMKO, G.T.

Neuronal correlates of an encephalopathy associated with aluminum neurofibrillary degeneration. Brain Research, v.97, p.253-264, 1995.

GARCÍA-FERNÁNDEZ, A.J.; SÁNCHEZ-GARCIA, J.A.; GÓMEZZAPATA, M.; LUNA, A. Distribution of cadmium in blood and tissues of wild birds. Archives of Environmental Contamination and Toxicology, v.30, p.252-258, 1996.

GREENWOOD, D.A., SHUPE, J.L., STODDARD, G.E. Fluorosis in Cattle. Utah Agric. Exp. Stn. Spec. Rep. 17. Logan, Utah, 1964. 36p.

HOOSER, S.B. Cadmium. In: GUPTA, R.C (Ed). Veterinary toxicology: basic clinical principles. New York:

Academic Press, 2007. p.422-426. 
JUNQUEIRA, O.M. Heavy metals contaminate the beef. Avicultura e Suinocultura Industrial, v.3, p.27-29, 1993.

LIMA, F.R.; MENDONÇA, C.X.; ALVAREZ, J.C.; RATTI, G.; LENHARO, S.L.R.; KHAN, H.; GARZILLO, J.M.F. Chemical and physical evaluations of commercial dicalcium phosphate as source of phosphorus in animal nutrition. Poultry Science, v.74, p.1659-1670, 1995.

LOPES, H.O.S.; PEREIRA, G.; PEREIRA, E.A. Evaluation of the heavy metals level and the fluorine in samples of dicalcium phosphate and super triple phosphate to animal nutrition. In: ANNUAL MEETING OF THE BRAZILIAN SOCIETY OF ANIMAL SCIENCE, 34, 1997, Juiz de Fora. Annals... Juiz de Fora : SBZ, 1997. p.462-464.

LOPES, H.O.S.; PEREIRA, L.G.R.; PEREIRA, E.A.; SOARES, W.V.; PEREIRA, G.; COSTA, M.F.V.; SANCHES, R.L.; GONÇALVES, L.C. Evaluation of the levels of fluorine, heavy metals and other minerals in bovine tissues that received super triple phosphate. In: ANNUAL MEETING OF THE BRAZILIAN SOCIETY OF ANIMAL SCIENCE, 37., 2000, Viçosa, MG. Annals... Viçosa, MG: SBZ, 2000 .

MARÇAL, W.S.; PARIZOTO JUNIOR, N.; STELLA, T.R.; SOUZA, R.B. Inorganic aluminum levels in mineral supplies to bovines available in markets of São Paulo State. Synergism Scyentifica, v.2, p.1-3, 2007.

MARÇAL, W.S.; GASTE, L.; LIBONI, M.; PARDO, P.E.; NASCIMENTO, M.R.; HISASI, C.S. Concentration of lead in mineral salt mixtures used as supplements in cattle food.

Experimental Toxicology and

Pathology, v.53, p.7-9, 2001.

MENDONÇA JÚNIOR, A.F.; BRAGA, A.P.; RODRIGUES, A.P.M.S.; SALES, L.E.M.; MESQUITA, H.C. Minerals: The Importance of Dietary Use of Ruminants. Agropecuária Científica no Semi-Árido, v.7, n.1, p.1-13, 2011.

MOREIRA, L.M.; LEONEL, F.P.; VIEIRA, R.A.M.; PEREIRA, J.C. A new approach about the digestion of fibers by ruminants. Brazilian Journal of Animal Health and Production, v.14, n.2, p.382-395, 2013.

NATIONAL RESEARCH COUNCIL NRC. Mineral tolerance of animals. 2.ed. Washington, D.C.: National Academy of Sciences, 2005. 510p.

NATIONAL RESEARCH COUNCIL NRC. Nutrient requirements of beef cattle. Subcommittee on Mineral Toxicity in Animals. Washington, DC: National Academy of Science, 1996. $234 p$.

NOMURA, C.S.; OLIVEIRA, P.V. Preparation of bovine liver sample and study of micro homogeneity to the determination of $\mathrm{Cd}$ and $\mathrm{Pb}$ by atomic absorption spectrometry with electrotermic atomization and direct obtaining of sample from solid.

Química Nova, v.29, n.2, p.234-239, 2006.

PHILLIPS, C.J.C.; CHIY, P.C.; OMED, H.M. The effects of cadmium in feed, and its amelioration with zinc, on element balance in sheep. Journal of Animal Science, v.82, p.2489-2502, 2004. 
SHIRLEY, R.L. Water requirements for grazing ruminants and water as a source of minerals. In: McDowell, L.R.

Nutrition of grazing ruminants in warm climates. Orlando: Academic Press, 1985. p.182-186.

SOUZA, M.V.; VIANNA, M.W.S.; ZANDIM, B.M.; FERNANDES, R.B.A.; FONTES, M.P.F. Heavy metals in biological samples of bovines. Ciência Rural, v.39, p.1774-1781, 2009.

TEIXEIRA, S.; BRANCO, A.F.; GRANZOTTO, F.; BARRETO, J.C.; ROMA, C.F.C.; CASTAÑEDA, R.D.

Phosphorus sources in mineral supplements for beef cattle grazing Cynodon nlemfuensis Vanderyst pasture. Brazilian Journal of Animal Science, v.40, n.1, p.190-199, 2011.
TEIXEIRA, A.O.; LOPES, D.C.; RIBEIRO, M.C.T.; LOPES, J.B; FERREIRA, V.P.A.; VITTI, D.M.S.; MOREIRA, J.A.; PENA, S.M. Chemical Composition of different phosphorus sources and heavy metals deposition in tissues of swines.

Brazilian Journal of Veterinary and Animal Sciences, v.57, n.4, p.502-509, 2005.

Data de recebimento: $12 / 11 / 2013$

Data de aprovação: 23/12/2013 